\title{
The Protection of Cultural Heritage in the Sultanate of Oman
}

\author{
Gugolz, Alessandro
}

\begin{abstract}
The Sultanate of Oman has enacted a modern and detailed statute protecting its cultural heritage. It is one of the newest and most modern pieces of legislation within the Arab world and provides broad protection for the rich cultural heritage of the country. The enactment of the statute and its application to protect culture and the nation's cultural heritage became an important political aim, and the year 1994 was officially declared as the "Year of National Heritage"
\end{abstract}

DOI: https://doi.org/10.1017/s0940739196000069

Posted at the Zurich Open Repository and Archive, University of Zurich

ZORA URL: https://doi.org/10.5167/uzh-154936

Journal Article

Published Version

Originally published at:

Gugolz, Alessandro (1996). The Protection of Cultural Heritage in the Sultanate of Oman. International Journal of Cultural Property, 5(02):291-309.

DOI: https://doi.org/10.1017/s0940739196000069 


\title{
Documents
}

\section{The Protection of Cultural Heritage in the Sultanate of Oman}

\author{
Alessandro Gugolz*
}

\section{Summary}

The Sultanate of Oman has enacted a modern and detailed statute protecting its cultural heritage. It is one of the newest and most modern pieces of legislation within the Arab world and provides broad protection for the rich cultural heritage of the country. The enactment of the statute and its application to protect culture and the nation's cultural heritage became an important political aim, and the year 1994 was officially declared as the "Year of National Heritage".

\section{Introduction}

The Sultanate of Oman has always been a junction of the trade routes linking the Far East, Eastern Africa and Europe. As an old seafaring nation, Oman has taken part in the cultural and economic exchange among many nations. Because of its position on one of the oldest trade routes, the legendary silk road, the country possesses a rich archaeological and architectural heritage (Stevens 1990: 7 et seq.; Popp 1994: 25 et seq.). Today Oman is a country with a quickly growing economy and stable government which plays a leading role as mediator within the Gulf and Middle East peace process (Staub 1995: 7).

His Majesty Sultan Qaboos bin Said Al Said laid the foundation for the country's economic development after he assumed leadership in 1970. The Sultan and his government established a well-planned policy to develop the country, while intending, at the same time, to avoid a too rapid modernization and adoption of western products and life-styles. Oil-export revenues are used for only reasonable development of the country. Preservation of the cultural heritage, protection of the environment, and ecology are important political aims (Malallah bin Ali bin Habib 1992: 20).

Oman, an absolute monarchy, does not have a written constitution (Ballantyne 1986: 159). The Sultan issues laws and decrees which are formulated in cooperation with the cabinet council of ministers and other consultative boards (Al-Zedjali 1993: 31 et seq.). Oman's

* Student of Law, University of Zürich Law School, Zürich, Switzerland. 
legal system is founded on the Shari'a, which is the basis for every ordinance and the primary source of law, as in other Gulf states (Pepper 1991: 331; Saleh 1994: 106). In addition to the Shari'a (Qur'ân and Sunna), different decrees (Qânûn) regulate the administrative law (Debs and Ziadeh 1986: 113).

In the Middle East, legislation regarding protection of cultural heritage is relatively young. However, it is important to ensure effective protection considering the growing market which is increasingly open to the western world and thus creates a danger of illicit trade in objects of great value to a nation's cultural heritage. Moreover, Kuwait (Melikian 1991: 4) and Yemen (Kocher 1995:7) are now trying to recover important art treasures that were lost during the Gulf War and the Civil War.

\section{The Protection of Cultural Heritage in the Sultanate of Oman in General}

\subsection{Ministry of National Heritage and Culture}

In order to maintain effective protection of cultural heritage, both a legal framework and enforcement of the laws are of great importance. The Sultanate of Oman pays serious attention to these concerns, and in 1977 the Ministry of National Heritage and Culture was created ("wizâra al-turâth al qawmî wa-l-thaqâfa": Ministry of National Tradition and Culture). The Ministry is obligated to protect tangible as well as intangible property - such as traditional professions, scientific and intellectual achievements - and to safeguard national traditions (Sultan's Decree 77/20).

A basic element for effective protection of cultural heritage is public awareness of the value of the nation's culture, even in a time when modern achievements draw attention to other matters. From a political point of view as well, the identification of people with their cultural past can play a key role in maintaining stability, especially in a country where many clans and different ethnic groups co-exist. His Majesty Sultan Qaboos bin Said and his government are aware of these factors, and therefore they officially declared the Year 1994 as the "Year of National Heritage".

\subsection{International Conventions}

On 2 June 1978, the Sultanate of Oman deposited its ratification of the UNESCO Convention on the Means of Prohibiting and Preventing the Illicit Import, Export and Transfer of Ownership of Cultural Property; the ratification became effective on 2 September 1978 (Saba 1984: 364). On 26 October 1977, the country ratified the UNESCO Convention on the Protection of Cultural Heritage in the Event of Armed Conflict (Saba 1984: 356). 


\subsection{National Legislation}

Relevant legislation for the protection of culture and heritage in the Sultanate of Oman includes the Sultan's Decree 6/80, issuing the Protection of National Heritage Law and containing general provisions regarding the organization and duties of the Ministry of National Heritage and Culture, and the Statute of the Protection of National Heritage, which entered into force in 1980 (reproduced in the appendix).

\section{Interpretation of the Statute for the Protection of Na- tional Heritage}

The scope of the expression "cultural heritage" varies according to national legislation. Even international conventions do not present uniform definitions. The term is dependent on circumstances, such as the artistic tradition of the country, and socio-cultural factors, as well as the nation's cultural consciousness (Jaeger 1993: 8).

\subsection{Definition of Cultural Heritage}

In its first two Articles, the Act defines the notion of "al turâth alqawmî" (national heritage) as protected by law. Article 1 describes the various categories which "national heritage" includes; Article 2 defines the terms specifically. Such a system is to be preferred (Jaeger 1993: 11), as the enumeration is not complete but leaves enough scope to integrate further categories and items.

\subsection{Comparison with the Catalogue of the UNESCO Convention of 1970}

In accordance with its nature, the Convention covers only movable cultural property as defined under Art. 1 of the Convention. The catalogue established in Art. 2 lit. d of the Protection of National Heritage Act of the Sultanate of Oman complies in general with the provisions of the UNESCO Convention and grants extensive protection.

There are, however, the following differences and peculiarities:

(1) The Act protects objects which are 60 and more years old, while the Convention requires antiquities (such as inscriptions, coins and engraved seals) and articles of furniture to be older than 100 years. For other categories of movable property, the Convention does not indicate a minimum age, leaving such limitations to the legislation of each State Party. With the "moving date system". (Prott and O'Keefe 1989: 24) and the ability to declare objects as cultural heritage by ministerial decision independent of their age, the system chosen by Oman provides more flexibility. 
(2) For objects of artistic value, the Act mentions categories of objects which are typical for the culture of the country but which the Convention does not mention, such as jewelry, weapons, objects of painted porcelain, and stone-engraved pictures. Moreover, the catalogue is open for categories and items which have not been mentioned explicitly (see Article la, Article 2 lit. d vii).

(3) The Convention applies to all cultural property found within the territory of each Member State (Art. 4), while the Protection of National Heritage Act of Oman also covers explicitly underwater cultural heritage (Article 2 lit. f) as a part of the national heritage.

\subsection{Registration of Cultural Heritage}

The Sultanate of Oman provides two forms of registration of its cultural heritage: a collective inventory (Art. 3) and an individual registration of objects of particular importance in a separate inventory (Art. 5 and 31).

\subsection{Immovable Cultural Property}

The law distinguishes between the protection of single monuments and that of building complexes and sites. In addition to an individual registered monument, the area surrounding the object or the visual range around it may also be protected (see Art. 8, Art. 10) ("majâl al-hazar": side, field in the visual range). Within this extensive formulation, the scope of protection of individual monuments may be determined. Private ownership of registered objects is also allowed, but registration implies restrictions of the owner's rights regarding the object.

A written license is mandatory for any archaeological excavation (Art. 20). Such a license fixes the conditions, obligations and rights of the excavator. The excavation is supervised by the ministry (Art. 26).

The state may acquire newly discovered monuments. The owner receives suitable compensation for the monument and the site (Art. 23). A temporary appropriation is also possible (Art. 24) if agreement with the owner of the property cannot be reached. The regulations establish a system to coordinate public and private interests. Guidelines regarding compensation are provided, but amicable ("ridâ": To agree amicably by "shaking hands") and flexible agreements between the parties are also possible. The scope of the regulations conforms with both the UNESCO Recommendation on International Principles Applicable to Archaeological Excavations of 1956 (Saba 1984: 375) and the recommendations formulated at the Symposium in Cairo in 1993 regarding the Protection of Cultural Heritage in the Middle East and Northern Africa. 


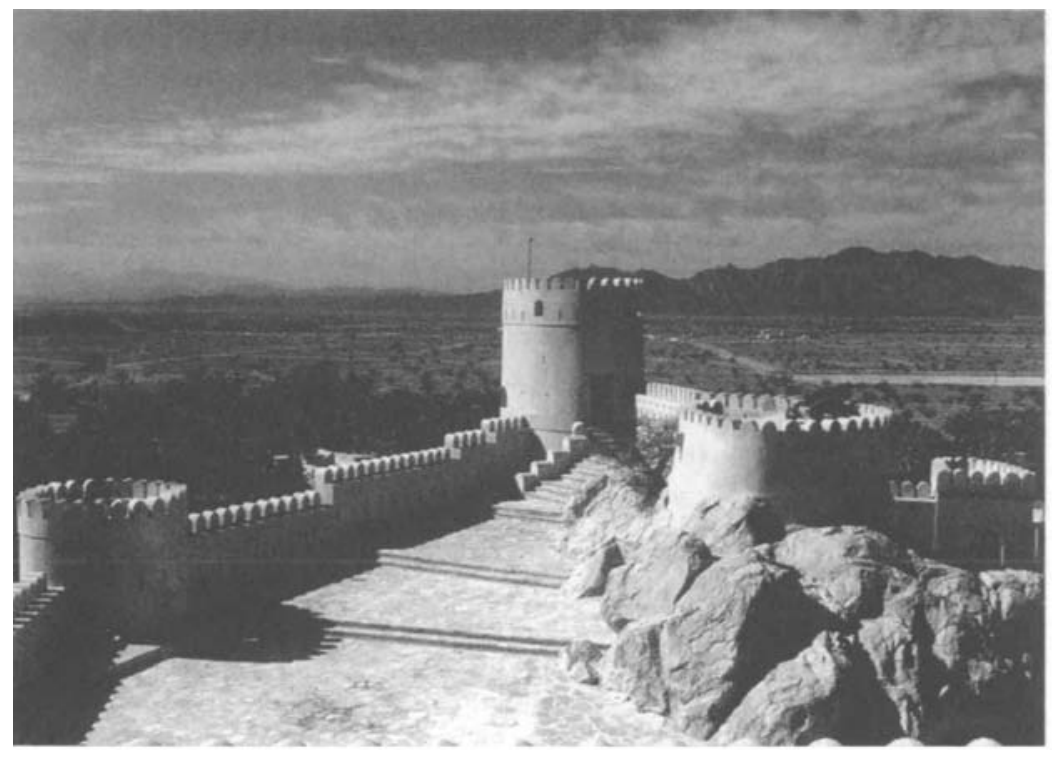

\subsection{Movable Cultural Property}

In the Sultanate of Oman, a large part of the cultural heritage is in private hands. Therefore it is important to provide broad and detailed legislation in order to identify cultural objects and to fix the rights and duties of owners.

All excavated movable cultural property must be reported to administrative authorities and is considered to be State property (Art. 21, 22) ("milkan li-l-dawla": State property, which includes the possession of the item). At the same time, the Law provides that a limited number of items may be "returned" to the person carrying out the work (see Art. 22 lit. b and c) ("juradd ilâ al- qâ'im": The object is transferred into the property of the person carrying out the work so that he becomes "al-mallak," owner of the item). In Islamic jurisprudence, the distinction between "proprietas" and "possessio" is not the same as in the Roman legal system (Debs and Ziadeh 1986: 93 et seq.).

The Sultanate of Oman has issued rules to regulate the transfer of cultural property and to prevent illicit export. Legislation aimed at prohibiting all trade in cultural property has not been effective in preventing illicit traffic, as experience has shown (Froua 1985: 95). In addition to regulation of the right to deal with cultural property, there are several restrictive provisions:

\subsubsection{Registration}

The listing of all movable cultural heritage in the collective inventory (Art. 3) and the registration of important objects (Art. 31) provide significant assistance in the prosecution of theft or loss of objects (see Art. 34 lit. b).
The newly restored Fort Nakhal 


\subsubsection{Trading with Movable Cultural Property}

Any sale of movable cultural property must be officially authorized (Art. 37). Dealers are required to record all objects in a separate register indicating the seller, purchaser, origin and source of each object (Art. 38). The purpose of registration is to facilitate prosecution of illicit traffic and to enable the authorities to prevent uncontrolled loss of cultural objects. Before a registered object may be sold, the owner is required to inform the Ministry of his intention and to provide the name and address of the prospective buyer at least two months before the sale is to take place. Without such information, the sale is null and void. This rule empowers the Ministry to make use of the power of preemption (Art. 35). Trade of registered objects owned by the government is absolutely prohibited and this provision is not negotiable (Art. 35).

If the object is registered, the Ministry provides "all necessary procedures" to stop export or illegal sale in case of disappearance (Art. 34 lit. b) and to obtain restitution of the property. This protection is not available if the owner or the person responsible failed to notify the Ministry immediately of the loss. Such an omission may lead to the confiscation of the object by the State without any payment of compensation. Official inspectors check for the proper and lawful keeping of the register (Art. 38).

\subsubsection{Export Regulations}

The export of any registered item of movable cultural heritage is prohibited, except for purposes such as public exhibition and museum display (Art. 33). Export of even non-registered objects requires an authorized license issued by the Ministry and containing a

Traditional Omani

Kanjiar (Photographs by courtesy of the author)

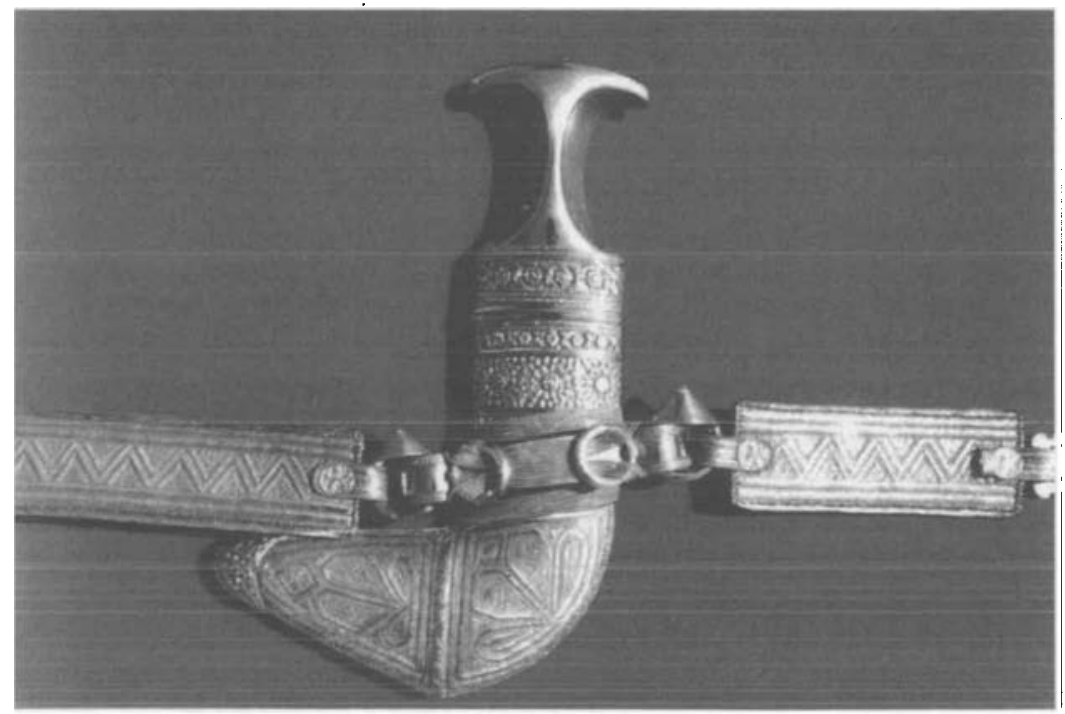


detailed description of the item. Every illegal export is a crime (Fechner 1991: 105). The Ministry engages actively in the search for stolen registered objects, in contrast to American law, where the owner is required to conduct an active search in order to bring a successful legal action (Siehr 1992: 58).

\subsection{Summary assessment}

The scope of the regulations regarding immovable as well as movable cultural heritage is very broad. An important aspect of this regulation is cooperation between private parties and the government. The Protection of Cultural Heritage Law of Oman differs from the legislation of the other Gulf States regarding the detailed and distinct mechanisms of protection.

\section{The Protection of Cultural Heritage in the Sultanate of Oman - A Practical Approach}

The Ministry of Culture and Heritage maintains close contact with international organizations such as UNESCO, which have listed the Fort of Bahla, the ruins of Qalhat and the tombs of Bat, Al-Ayn and $\mathrm{Al}$-Khutm in the inventory of World Heritage. Listing has been proposed for "Jidat al Harassis" where the endangered Oryx Antelope has been given a protected area (Sultan's Decree 4/94). The UNO recognizes Oman as one of the exemplary countries which implement the in fact conventions and recommendations and proceed to act UNO's on them (Popp 1994: 20). The Sultanate of Oman can boast of having more historic buildings per square kilometer than the majority of Arab countries (Walls 1978: 11). The restoration of historic citadels, forts, palaces and similar monuments is a carefully planned activity, well organized and carried out continuously by the Ministry. The year 1994 was officially declared the "Year of National Heritage".

Nizwa is the traditional center of Oman's religion, Ibadhism. Distinct from the Sunni and Shi'a schools, the Ibadhi school represents a minority tradition in Islamic constitutional law (Amin 1989: 46). The doctrine is based on the Qur'an, the Sunna, consensus (ijmâ) and analogy (qiyâs) (Amin 1989: 193). In Nizwa, a great "village of culture" is under construction, which will exhibit all aspects of culture and tradition in Oman. Several other projects are in preparation or have already been realized (Al-Harthy 1994: 12-23).

All this demonstrates that preservation of and respect for its culture are real concerns for Oman. The country is prepared to integrate its historical culture into the renaissance which is taking.place today in the Sultanate of Oman. 
Appendix

\author{
Sultani Decree \\ No. $6 / 80$ \\ Issuing the Protection of National Heritage Law
}

We, Qaboos bin Sa'id, Sultan of Oman,

After taking cognizance of Sultani Decree No. 26/75 issuing the Organization of the State Executive Administration Law and its amendments; Sultani Decrees No. 69/77 adhering the Sultanate of Oman to the International Agreement on Procedures to Forbid the Import, Export and Transfer of Ownership of Cultural Property Illegally; Sultani Decrees Nos. 12/76 and 14/76 Modifying the Council of Ministers and Creating the Ministry of National Heritage and Culture; Sultani Decree No. 64/78 issuing the Expropriation for Public Benefit Law; and in accordance with the public interest.

Have issued the following Law:

Article 1: The provisions of the attached law shall be applied and it shall be called "The Protection of National Heritage Law".

Article 2: The Minister of National Heritage and Culture shall execute this Law and he shall seek advice from a ministerial committee formed by the Ministers of the Interior, Social Affairs and Labour, Land and Municipal Affairs and the Permanent Secretary for Financial Affairs before making any final decisions in accordance with the provisions of the attached law on matters of joint interest.

Article 3: A special Committee for the Preservation of National Heritage shall be formed under the chairmanship of the Minister of National Heritage and Culture whose members will be chosen by the Minister from representatives of interested government departments and individuals with experience in the affairs of cultural property and in public relations. The committee shall be entrusted with the following basic matters:

(a) to give their opinion and recommendations on whatever matters the Minister of National Heritage and Culture refers to it which concern the protection of cultural property and the development of the citizens' awareness of their national heritage,

(b) strengthening the people's interest and participation in the preservation of the national heritage,

(c) to establish the rules for the meetings of the committee.

Article 4: All Ministries and other governmental departments shall take the necessary steps, each within its responsibilities, to execute the provisions of this Decree and the attached Law. 
Article 5: This Decree shall be published in the Official Gazette and shall take effect from the date of its publication.

Qaboos bin Sa'id

Sultan of Oman

Issued on: 23rd Rabi'al-Awal $1400 \mathrm{AH}$.

10th February 1980 AD.

\section{Protection of National Heritage Law}

Article 1: In the application of this law, National Heritage shall mean:

(a) antiquities of all kinds,

(b) movable cultural property including objects found in archeological diggings and items which were originally parts of archeological monuments or sites,

(c) complexes of archeological buildings.

Article 2: Definitions: For the purpose of this law, the following terms shall have the meanings given opposite each of them, unless otherwise stated:

(a) the Ministry $=$ the Ministry of National Heritage and Culture.

(b) the Minister $=$ the Minister of National Heritage and Culture.

(c) archeological monument = any building, construction, ancient hill, cemetery, cave, rock, statue, engraving on stone which shall have a historical, archeological, artistic or scientific value and which dates to a period of not less than sixty years or which was the subject of a Ministerial Decision naming it as an archeological monument. The term "archeological monument" includes its site and any part of the land necessary for fencing it, protecting its shape or artistic appearance or in any other way.

(d) movable cultural property $=$ movable property of value in archeology or history, art or science and which dates to a period of not less than sixty years or which was the subject of a Ministerial Decision naming it as a movable cultural property and falls within the following categories:

i- rare collections and specimens of animals, plants, metals, anatomy and important items related to paleontology,

ii- historical property,

iii- findings of archeological diggings (authorized or not authorized) and archeological discoveries,

iv- pieces which were part of broken artistic or historic monuments or from archeological sites, 
v- archeological items such as engravings, coins and seals,

vi- items of ethnological value,

vii- property of artistic value, including:

* hand-made pictures, paintings and drawings whatever material they are made of or made on,

* original statues and sculptures whatever material they are made of,

* original stone-engraved pictures, drawings or prints,

* original artistic assemblies and constructions of whatever material,

* rare manuscripts, old books, documents and prints of special value (historical, artistic, scientific or literary) other than those protected by Sultani Decree No. 70/ 1977 ,

* furniture of traditional style, painted porcelain, musical instruments, jewelry, weapons and other items,

(e) building complexes = any group of buildings, separate or linked together, which have special value historically, artistically or scientifically with regard to their architectural design or homogenous style or place in the natural surroundings.

(f) archeological diggings = any search for items of archeological nature whether by digging into the earth or on its surface, on the sea-bed, underwater or in inshore water.

\section{Inventory}

Article 3: A collective inventory for the State shall be prepared, which shall be made complete continuously. It shall contain all property which constitutes the National Heritage. A Sultani Decree shall define the methods and procedures to be followed in preparing the inventory. The Decree shall name the organizations charged with this mission.

Article 4:

(a) It is forbidden for any person, whether owner of the monument or not, to destroy it or transfer it, whether partially or totally, or divide it or deface it or modify it or harm it or change its form in any way or dig, excavate, plough or cause any other changes to the land surrounding or neighboring the monument unless that person possesses the written agreement of the Ministry or of an official authorized to give such an agreement.

(b) If the provisions of the previous paragraph are contravened, the Ministry may issue an order to repair that monument and return it to its previous state and form at the expense of the contravenor who shall be, in addition, punished by a fine not exceeding 50 riyals or by imprisonment for a period not exceeding three months or by both.

(c) The Ministry may entrust its officials, who are charged with this work, to inspect the monuments at any time and from time 
to time and to submit reports on them. Any official charged with this work may visit the monument for inspection and carry out whatever he deems necessary for executing his mission subject to notifying the owner of the monument of his visit at least twenty four hours before it takes place.

\section{Registered Monuments}

Article 5: The Minister may, on his own initiative or at the request of the owner or the person responsible for a monument of substantial importance historically, artistically or scientifically, declare that the monument is a Registered Monument.

Article 6: The declaration mentioned in the previous article shall be notified to the owner or the person responsible for the monument. The notification shall specify that any objection made against this declaration within sixty days of the date of notification will be the subject of an immediate inquiry by the Ministry.

Article 7: A copy of the notification shall be placed at the principal site of the monument and another copy shall be placed at a place near the site. At the end of the sixty days' period, the Minister may, after examining the objection, withdraw his declaration or confirm it.

Article 8: The Ministry shall prepare an official list of Registered Monuments, which shall be kept up-to-date continuously. The list will contain a brief description of the Registered Monument stating its geographical location and specifying the protected area surrounding it. The list shall also contain the names and addresses of the owners or the persons responsible for the monument, as the case may be, and the date of its registration.

Article 9: Any person who destroys, demolishes, transfers, changes, defaces or carries out any act which may result in the loss of or damage to any Registered Monument shall be punished by a fine not exceeding two hundred riyals or imprisonment for a period not exceeding one year or both.

Article 10: Without prejudice to the provisions of article 4 which applies to all monuments, registered or unregistered, no building can be built adjacent to a Registered Monument or within its visual range without written permission from the Ministry.

Article 11: Prior permits shall be obtained before any electrical or telephone cables can be laid, whether under or on top of the ground or any gas or petroleum pipes can be laid, whether they are for enlarging, repairing or improving existing buildings internally or externally and for all work involving painting, leveling (vertically or horizontally), plumbing, carpentry or water drainage if they are affecting any Registered Monument. 
Article 12: No advertising of any kind shall be allowed inside, outside or within the visual range of Registered Monuments whether such advertising takes the form of posters, neon signs, vocal messages or any other kind.

Article 13: In the event that any of the provisions of Article 10, 11 or 12 above are contravened, the Ministry may order the restitution of the Monument to its original state at the expense of the contravener. In addition the contravener shall be punished by a fine not exceeding one hundred riyals or by imprisonment for a period not exceeding six months or both.

Article 14: The Ministry shall be immediately notified of the sale of any Registered Monument. Failure to notify the Ministry shall result in the nullification of the sale.

\section{Preserving, Maintaining, Repairing and Visiting Registered Monuments}

Article 15: Every owner of a Registered Monument or the person responsible for it shall carry out all the necessary procedures to preserve it and maintain it.

\section{Article 16:}

(a) The Minister may demand of the owner of a Registered Monument or the person responsible for it, as the case may be, to submit a written undertaking containing the necessary procedures and arrangements in accordance with the provisions of Article 15 above.

(b) The undertaking stated in paragraph (a) above shall contain the following points and any other necessary points:

* maintenance of the monument, duties of the persons responsible for the monument and its security,

* facilities accorded to the public to visit the monument and to the Ministry's officials delegated to inspect and protect archeological monuments,

* sale of land on the site of the monument to the Government of the Sultanate of Oman at a price to be fixed according to the current prices or to the provisions of the Expropriation in the Public Interest Law,

* a Ministry-appointed organ to solve any conflict related to the subject of the undertaking.

Article 17:

(a) The Ministry may, on its own initiative or at the request of the owner or the person responsible for the monument, take the necessary procedures to preserve a Registered Monument which needs major support, repairs or restoration provided that the Ministry shall be responsible financially for a part of the costs. 
(b) For the purpose of the previous paragraph, support, repairs or restoration is considered major work if its cost exceeds the monument's income for two years or, if the monument has no income, its total maintenance costs during the last three years.

(c) The amount of financial assistance to be borne by the Ministry shall be determined taking in consideration the national importance of the Registered Monument, its present condition, the nature of the work which is required and the extent of the financial participation of the owner and other interested parties.

Article 18: In the case of an agreement being reached between the Ministry and the owner or the person responsible for the monument, a contract shall be drawn between the concerned parties in which the nature of the work which is to be carried out is defined as well as the method by which it can be carried out, the share of each party in the costs and the terms and dates of its payment. The Ministry shall supervise the work and its technical departments may carry it out themselves, if they see fit to do so.

Article 19: In the case that the owner of a Registered Monument does not maintain it satisfactorily in contravention to the provisions of Article 15 or in case he refuses to carry out the work specified in Article 17, the Ministry may appropriate the registered Monument without payment of any compensation. However, if the failure to maintain the Registered Monument or refusal to carry out the work required by the Ministry is due to the insufficiency of the owner's financial resources, the monument is then appropriated and the owner is compensated in accordance with the provisions of the Disappropriation of Property in the Public Interest Law.

\section{Diggings}

Article 20: It is forbidden to start archeological diggings without a written permit from the Ministry.

(a) The permit shall define the general and special terms to the granting of the concession, the rights, and duties of the concessionaire and the duration of the concession.

(b) Without prejudice to the Ministry's right to compensation and confiscation, any contravention to the provisions of the previous paragraph shall be punished by a fine not exceeding one hundred riyals or by imprisonment for a period not exceeding six months or both.

Article 21:

(a) If, as a result of construction work or under any other circumstance, monuments or archeological items are discovered, whoever has found them and the owner of the land where they were found shall notify the nearest administrative authority of 
their discovery and the administrative authority shall notify the Ministry of this discovery.

(b) The person who discovered the items and the owner of the land shall be held responsible for keeping the discovered items temporarily until they are handed over to the competent administrative authority.

(c) Without prejudice to the right to any compensation due, failure to report accidental discovery of archeological items shall be punished by a fine not exceeding one hundred riyals or by imprisonment for a period not exceeding six months or both.

Article 22:

(a) All movable archeological items discovered during diggings or by any accident shall be the property of the State whatever the legal situation of the land where they were found.

(b) The permit for digging may state that a limited number of items found in the diggings shall be returned to the person carrying out the work, if they were similar to other items found in the same digging and can be dispensed with.

(c) Items referred to in the previous paragraph can be returned to the person who carried out the digging, always provided that he undertakes to hand them over for a fixed period to a museum or other scientific center open to the public. If he refuses to hand them over or fails to leave them there during the fixed period, these items will be returned to the possession of the State.

(d) The Ministry shall pay reasonable compensation to any person who accidentally discovers an archeological item and reports it in accordance with the provisions of Article 21.

Article 23: If, during digging or by accident, a monument is discovered whose foundations are still embedded in a land which is not the property of the State, the State may acquire the property of the monument and the site on which its foundations stand against payment of appropriate compensation to the owner estimated on the basis of the value of the land and buildings erected on it before the discovery of the monument but not taking in consideration the value of the monument itself whether agreed upon amicably or in accordance with the provision of the Disappropriation of Property in the Public Interest Law.

Article 24: If the Ministry decides to carry out diggings by itself or gives permission for diggings to be carried out on land which is not the property of the State, the Ministry may, if it does not reach an agreement with the owner of the land, decide to appropriate the land, temporarily, in accordance with the provisions of Article 25 below.

Article 25: The Ministry shall fix the period of temporary appropriation. At the time of appropriation a description of the state of the site is prepared and agreed by the two parties. Compensation shall 
be paid for the temporary appropriation in accordance with the provisions of the Disappropriation of Property in the Public Interest Law. At the end of the period of appropriation - with the exception of cases where the diggings result in the discovery of a static monument - the site is returned to its original state by the Government at its expense.

Article 26: In all cases where diggings are carried out by virtue of a Permit issued by the Ministry, the work shall be carried out under the supervision of the competent Government Department.

\section{Protection and Preservation of Movable Cultural Property}

Article 27:

(a) It is forbidden for the owner or any person to destroy, deface, damage or paint movable cultural property.

(b) Provisions of paragraph (a) above shall not apply to the restoration of movable cultural property if the work has been authorized by the Ministry.

Article 28: It is absolutely forbidden to export any movable cultural property without the written permission of the Ministry. The permission shall be in the form of an Export License carrying a detailed description of the said property.

Article 29: Any contravention of the provisions of Articles 27 and 28 shall be punished by a fine not exceeding one hundred riyals or by imprisonment for a period not exceeding six months or both.

Article 30: The export of modern artistic objects made by native craftsmen is not subject to any restrictions or permits. The Ministry shall stamp such objects, at the request of interested parties, to facilitate proof of origin and eventual export.

\section{Registration of Movable Cultural Properties}

Article 31: The Ministry shall decide which movable cultural property has such importance historically, artistically and scientifically that its loss shall constitute a great deprivation to the National Heritage and shall consequently declare it as a Registered Movable Cultural Property. The Ministry shall inform the owner of the cultural property or the person responsible for it, as the case may be, of this decision. The owner or person responsible may object to the Minister about the said decision during sixty days from the date he was informed. The Minister shall decide after the period of sixty days whether to withdraw his decision or to confirm it.

Article 32: The Ministry shall prepare a list, which shall be kept upto-date continuously, containing a detailed description of every unit of Registered Cultural Property, stating its location and the name and address of the owner or the person responsible for it. 
Article 33:

(a) It is forbidden to export Registered Movable Cultural Property units.

(b) However, the Ministry may, exceptionally, give permission for the provisional export of Registered Cultural Property for a period not exceeding six months as a loan to foreign States, cultural organizations or museums for public exhibition or for educational or scientific research purposes, provided that the Ministry obtains sufficient guarantees for their restitution and their insurance against all risks of damage and theft.

Article 34:

(a) The owner of a Registered Movable Cultural Property or the person responsible for it shall be responsible for its safety and maintenance in a good condition.

(b) In case of the above-mentioned property, the owner or the person responsible for it shall notify its disappearance to the Ministry immediately. The Ministry shall take all the necessary procedures to stop its export or illegal sale and to restitute it.

Article 35: Registered Movable Cultural Property owned by the Government shall not be negotiable and their ownership rights shall not be extinguishable for any reason. Those which are owned by persons may be sold, but, to avoid the annulment of such sale, the owner shall inform the Ministry of his intention to sell and give the names and addresses of the prospective buyers before the sale takes place by two months, at least. The Ministry may use their right of preemption during that time.

Article 36: Any contravention of the provisions of Article 33 or 34 (b) shall be punished by a fine not exceeding two hundred riyals or by imprisonment for a period not exceeding one year or both. In addition the aforementioned Registered Movable Property shall be confiscated by the State without payment of any compensation.

\section{Purchase and Sale of Movable Cultural Property} Article 37:

(a) No person can, without a permit from the Ministry, deal in movable cultural property. No money lender can accept movable cultural property as guarantee or lien for loans.

(b) The permit is issued, initially for one year but can be renewed annually on payment of dues to be fixed periodically. A person holding such a permit shall be known as an "Authorized Dealer in Movable Cultural Property." The Ministry may cancel such a permit at anytime or refuse to grant it to any person who has committed a contravention of the provisions of this law.

Article 38: Every authorized dealer in Movable Cultural Property shall keep a register in accordance with the regulations issued by 
the Minister in compliance with this law. The register shall contain a list of the aforementioned Cultural Property, the names of the vendor or the purchaser, as the case may be, its origin and source. The register shall be available to the competent inspectors at all reasonable hours at his place of work.

Article 39: Authorized Dealers shall clearly display in their shops and offices posters carrying the provisions of this law concerned with the export of Movable Cultural Property in both Arabic and English.

Article 40: Contravention of the provisions of Articles 37, 38, or 39 above shall be punished by a fine not exceeding 20 riyals or by imprisonment for a period not exceeding three months or both.

Article 41: Articles 37, 38, 39 and 40 above shall not be effective immediately. The Ministry shall determine the date when they shall become effective.

\section{Protection of Building Complexes and Sites}

Article 42:

(a) The Minister may declare any building complexes of great historical, artistic or scientific value as a Registered Building Complex.

(b) The Minister's decision shall be displayed prominently near the complex. Any objection against the Minister's decision submitted within sixty days shall be considered by the Minister.

(c) At the end of the period of sixty days, the Minister may, after examining the aforementioned objection, withdraw his decision or confirm it.

Article 43: The Ministry shall prepare and keep an official list of all Registered Building Complexes. The list will contain a brief description of the Registered Building Complexes, their geographical locations, the limits of the protected areas surrounding them and names and addresses of their owner or persons responsible for them as well as the dates of their registration.

Article 44: Without prejudice to the protection enjoyed by the Registered Building Complexes by virtue of the statutory provisions and, in particular, Municipal and Urban Development Laws and Regulations, these Registered Complexes are also subject to the provisions of Articles 45, 46 and 47 below.

Article 45: It is strictly forbidden for any person, even the owner, to carry out modifications of Registered Building Complexes or within its visual range without a special written permission issued by the Ministry. This prohibition covers, in particular, building work, uprooting trees, laying of electric wires and telephone cables, whether above or below ground, gas and petroleum pipelines, external exten- 
sions, repairs and restorations to existing buildings, any external painting, joinery and drainage.

Article 46: Owners shall remain responsible for the maintenance of the buildings which constitute Registered Complexes or Registered Sites. However, if the Government considers that a major repair or improvement of a Registered Building Complex is necessary, the Ministry shall pay part of the costs. The Ministry shall reach an agreement with the owner related to the execution of the work.

Article 47: All publicity, whether in the form of poster advertisements or any other form and which shall have light or sound effect, is forbidden within the area of a Registered Building Complex or within its view range, with the exception of licenced signs inside the buildings in accordance with conditions specified by the Ministry.

Article 48: In addition to the obligation of every person who contravenes the provisions of Articles 45 or 47 to return the area to its original appearance at his own expense, the said person shall be punished by a fine not exceeding one hundred riyals or by imprisonment for a period not exceeding six months or both.

Article 49: Summary Courts throughout the Sultanate shall be competent to hear cases of contravention of the provisions of this law.

Article 50: Any previous legislation which contradicts the provisions of this law is nullified.

\section{Bibliography}

Al Harthy, Said bin Khalfan (ed.). 1994. Oman People \& Heritage. Muscat: The Oman Daily Observer: 12-23.

Al Zadjali, Abbas bin Ghulam Rasool. 1993. Oman 1993. Muscat: The Ministry of Information.

Amin, Sayed Hassan. 1989. Islamic Law and its Implications for the Modern World. Glasgow: Royston.

Ballantyne, W.M. 1986. Arbitration in the Gulf States: A Comparative Study. In The Arab Law Quarterly Vol. 1. London: Graham \& Trotman: 158.

Debs, Richard and Ziadeh, Farhat J. 1986. Der Begriff des Eigentums im islamischen Recht. In May, R. (ed.) Beiträge zum islamischen Rechtsdenken. Stuttgart: Franz Steiner Verlag Wiesbaden GmbH: 93.

Fechner, Frank. 1991. Rechtlicher Schutz archäologischen Kulturguts. Berlin: Duncker \& Humblot.

Fraoua, Ridha. 1985. Le Traffic Illicite des Biens Culturels et leur Restitution. Fribourg: Editions Universitaires.

ICOMOS U.S.A. 1994. The Protection of Cultural Property in the Middle East and North Africa: A Regional Symposium on the Effects of Public Policy in Cairo, Egypt, Nov. 13-19, 1993, Unpublished Recommendations.

Jaeger, Andrea. 1993. Internationaler Kulturgüterschutz. Cologne/Berlin/Bonn/ Munich: Heymanns.

Kocher, Victor. 1995. Südarabische Altertïmer als Kriegsbeute. In Neue Zürcher Zeitung, 09.01.1995: 7. 
Malallah bin Ali bin Habib. 1992. Outline of the History of Oman. Muscat: The Ministry of Information.

Melikian, Souren. 1991. Art Treasures among Kuwaiti. In International Herald Tribune 30/31 March 1991: 4.

Pepper, William F. 1991. Oman - Law and Jurisprudence. In The Arab Law Quarterly Vol. 6. London: Graham \& Trotman: 331.

Popp, George. 1994. Oman. Nürnberg: BW Verlag.

Prott, Lyndel V. and O'Keefe, P.J. 1989. Law and the Cultural Heritage, Volume 3: Movement. London and Edinburgh: Butterworths.

Saleh, Samir. 1994. Fading Vestiges of the Shari'a. In The Arab Law Quarterly Vol. 1: London: Graham \& Trotman: 106.

Siehr, Kurt. 1992. Zivilrechtliche Fragen des Kulturgüterschutzes. In Reichelt, Gerte (ed.), Internationaler Kulturgüterschutz, Vienna: Manz: 41.

Staub, Ignaz. 1995. Der Golf muss friedlich bleiben. Interview with His Highness Sayyd Haitham. In Tages Anzeiger der Stadt Zürich, 31.05.1995: 7.

Stevens, Andree. 1990. Oman - Citadels between Sand and Sea. Winksele, Belgium: Terra Incognita.

Walls, A.G. 1978. Sultanate of Oman. Preservation of Monuments and Sites. Paris: UNESCO.

UNESCO (ed.). 1984. The Protection of Movable Cultural Property I, Compendium of Legislative Texts. Vol. 1. Paris: UNESCO. 